\title{
Innovation vs. Innovativeness: \\ Do We Support Our Students in (Re-)Inventing the World?
}

\author{
Thomas Jekel, Nicole Ferber and Kirstin Stuppacher \\ University of Salzburg, Austria·thomas.jekel@sbg.ac.at
}

Full paper double blind review

\begin{abstract}
This contribution suggests that there is a major divide between using innovative tools such as GIS and geomedia in education, and using these tools to actively foster innovativeness. It takes two steps to argue that fostering innovativeness should be at the center of geomedia use in education: Firstly, it examines concepts of innovation and innovativeness in regard to potential geomedia uses in school. Secondly, we analyse English language contributions to the GI-Forum in regard to their use of the term innovation. We finally suggest that geomedia use should be re-examined, and at least partially used to support innovativeness, based on visual analytics approaches and storytelling.
\end{abstract}

\section{Introduction}

We do not exactly define what innovation is. To do that, both the public, as well as the academic discussion are too fuzzy. However, we'd like to point out that 1) a mantra of innovation is hurled at society in general, and education in particular, and 2) that this mantra is highly ideological and serves interests that are usually beyond general education. According to GoDIN (2014), most of the innovation talk is just that - talk. Accordingly, we are discussing which interest group uses the term to what end.

Innovation is deemed one of the central agents in competitiveness on a regional and a national scale, as well as on an individual level, in public discourse. At the same time, national and European Union initiatives try to foster innovation through multiple programs and incentives, including research and SME support (see, for example http://europa.eu/pol/ pdf/flipbook/en/research_en.pdf; Horizon 2020; COSME-programme).

In science, this search for an economical competitive edge through innovation may be most pronounced in regional development literature. Innovation, and the organization of innovation, has been widely discussed from early on in economic geography, under a host of different concepts. This has included the theory of redundancy and literature on Industrial districts (see GRABHERR 1992; AMIN \&THRIFT 1994; TÖDTLING 1994); research on innovation networks and creative milieus (FrOMHOLD 1995; JEKEL \& FROMHOLD 2003; KÖNIG et al. 2011); learning regions (RUTTEN 2007) and clusters. There seems to be a consensus in this literature regarding a variety of preconditions of innovation. These include competition, cooperation, and flexibility; diversity in a range of domains including origin and sexuality; 
an 'institutional thickness' with a variety of institutions ploughing the same field (i.e. chambers of commerce, companies and institutions of research and education, AMIN 1994).

In secondary education, innovation is used in a rather different context. It usually is understood as bringing new learning arrangements and technologies to school. This type of activity has been widely supported by a variety of funding agencies. EC Programmes, national agencies, and also private companies (i.e., the Innovative Learning Network) have taken innovation on board. However, we suggest that the assumption of innovative learning arrangements fostering innovativeness is far-fetched. The authors could not find published empirical data on that assumption. Especially in the beginning of geomedia use in school, innovative technologies were used to transport very traditional geographical knowledge, including traditional regional geography as well as an understanding of the world clearly linked to the spatial approach (see JEKEL 2007). Supporting innovativeness simply was not on the agenda - the knowledge imparted was either technical skills (GRYL \& JEKEL 2012), or even just another way to impart existing knowledge, albeit with better, or simply, different, visualisation - hoping for better results in reproduction of the same knowledge. Both ideas seem to be a rather narrow concept of innovation - sometimes no innovation at all.

This paper therefore seeks usable definitions of the terms innovation and innovativeness. It argues that innovativeness is a precondition for innovation, and not the other way round. Thinking along these lines, innovativeness allows students to 'invent the world' (GRYL et al. 2014). We look into conceptions of learning that foster innovativeness, which have been empirically tested. In the second part, we look into the way current academic and practical literature of geomedia based learning fits these definitions. We conclude that current learning technologies and learning environments rarely foster innovativeness, and we may have to rethink our learning and teaching strategies in this respect. First hints at possible avenues are provided in the discussion section of the contribution.

\section{Innovation and Innovativeness}

In her study of innovation concepts for use in secondary education, GRYL (2013:17) identifies a series of ideas that may be used to describe innovation. Firstly, she points out a difference between the general call for being innovative (these calls being an agent in political discourse), and scientific concepts describing innovation. In science, she differentiates according to social / cultural science ideas of innovation - innovations that change existing rules in society, and an economic perspective on innovation. Economic innovation then would link into changing products and processes, using institutional reflexivity for optimizing production of both goods and services. Looking into pedagogical literature from geography education, economic innovation may be linked to either a technical or pragmatic interest in learning and teaching (VIELHABER 2001, JEKEL 2006). A change in production routines requires 'invention', as well as the ability to implement this invention within the organization or company. In many cases, 'bringing together ideas that have not been connected before in a specific way' (JEKEL \& FROMHOLD 2003) usually would be the starting point of this process. A change in the more general rules governing societal life requires a critical-emancipatory interest in teaching, according to Vielhaber, breaking - if needed rules accepted by wider strata of society. To do so, the reflection of existent rules is mandatory. It has to be noted that critical-emancipatory concepts are conspicuous by their ab- 
sence, or at least underrepresented in Austrian and German legal documents of Geography education. Innovation does not have to be completely new, but can be dealt with as contextspecific, and therefore as rather local in outreach. It is this local dimension that allows the concept to be transferred into secondary education, aiming at reasonable ideas of innovation. For this paper, we'd like to broadly define innovation as an intended and positively associated change of various scales, based on an idea that breaks with current economic or societal rules, the implementation of which may have both intended and unintended consequences (see GRYL 2013, 18).

Innovativeness now means being able to innovate. This is an explicitly different wording from reactively being able to adapt to specific situations. Innovativeness therefore puts the students ability to innovate, to be an actor and an agent of change in the center. We may argue that there are several common denominators of being able to innovate (see GRYL 2013):

- The reflexive and creative act of transforming an existing situation and existing routines into a problem;

- The creative act of invention, based on hypotheses and oriented at problem solving, and finally;

- The implementation of the invention through communication and participation in discourse.

We may have to ask on a very general level how school is able to support the above dimensions of innovativeness, and, especially, which role geomedia may play in this regard. To get an idea of the current usage of the term innovation within the community, we conducted an exploratory content analysis of GI-Forum contributions published in the domain of learning with geomedia.

\section{An Exploratory Content Analysis of Geomedia Learning Literature}

So far, two empirical content analyses have been performed, based exclusively, or mainly, on pedagogical texts published in the GI-Forum. GRYL \& JEKEL (2012) noted that most papers up to that date were aimed at technical expertise, while close to none could claim to serve an emancipatory interest in learning, and therefore to support innovativeness in a wide sense. In another content analysis, SCHULZE \& KANWISCHER (2012) could show that little systematic empirical research had been done in the domain of learning with geomedia. Both studies are relevant as they hint at a lack of support for innovativeness in geomedia based learning without really touching the central assumptions concerning innovativeness listed above.

For an exploratory analysis of geomedia based learning, we analyzed all papers that had been in either the GI_Forum or Learning with GI-proceedings in English language, i.e. starting from $2007-\overline{2} 014$. The total number of papers included was 116 . Analysis was undertaken in two steps: First, a count of terms used that are rather closely related to innovation to explore the field and identify avenues for hypothesis generation; Second, a selective qualitative analysis of the context of the three most important terms, i.e. the concept and meaning in which the terms innovation and innovativeness have been used. 
The word field in figure 1 was elaborated from a collection of synonym terms of the words innovation, invention and inventive with the help of the web page http://www.thesaurus.com/. The word field consisted of 33 keywords, which were used for an explorative text analysis. Here the keywords were extracted from 116 paper contributions. The frequency of keywords was derived by the text analysis tool ConText (http://context.lis.illinois.edu/).

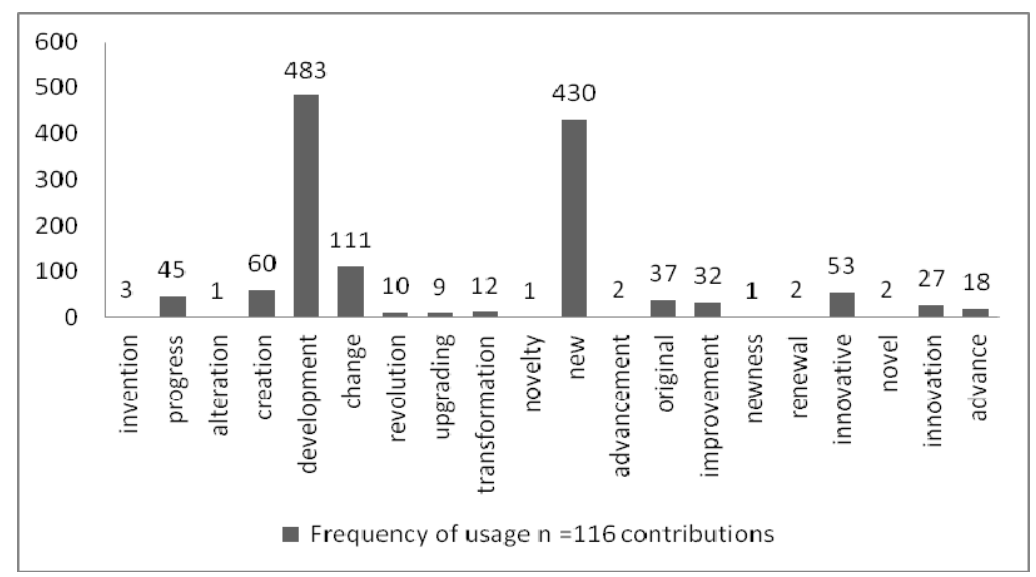

Fig. 1: Frequency of innovation related terms in the Learning with Geomedia field (multiple usages within contributions possible)

Looking at the results, we may conclude a high occurrence of terms commonly linked to innovation (like 'new' or 'development'); 'Innovation' and 'innovative' account for 80 occurrences, while invention merely occurs in three different articles once. Overall, 50 articles mention the keywords innovation, innovative, and invention. The keyword innovativeness does not occur at all.

In a second step, we concentrated on the occurrences of 'innovation', 'innovative', and 'invention'. These were set into their context and coded according to their meaning in regard to learning processes. A very rough system was used to determine the meanings in which the single term was used (see table 1). Categories were developed from our reading and interpretation of the texts, and from the suspected impacts 'innovation' and 'innovative' have on teaching and learning strategies, and, additionally, if they were aimed at teacher or student level.

The qualitative content analysis is based on techniques for systematic text analysis and the categories are central to the analysis. Following the research question, the material is analyzed under the proposed category system (table 1), which were under an ongoing revision during the analysis process.

The creation of categories (see table 1) is a result of key words mentioned in 50 GI_Forum contributions that deal with topics concerning "Learning with GI". The categories show different levels of innovation and innovativeness in ascending order. The idea is to find innovative educational concepts on a student level. If the aim of the texts is to foster innovation for teachers or education of teachers, they are summed up in the category "others". 
Tab. 1: Categories of content analysis:

\begin{tabular}{|c|c|c|c|}
\hline Category & Definition & Example & \\
\hline $\begin{array}{l}\text { Innovative tech- } \\
\text { nologies on pupils } \\
\text { level }\end{array}$ & $\begin{array}{l}\text { innovative technology used to } \\
\text { transport classical knowledge }\end{array}$ & $\begin{array}{l}\text { using digital globes for locating } \\
\text { countries, using games like } \\
\text { toporopa for learning topograph- } \\
\text { ical orientation knowledge }\end{array}$ & 4 \\
\hline $\begin{array}{l}\text { Innovative educa- } \\
\text { tion for pupils low } \\
\text { level }\end{array}$ & $\begin{array}{l}\text { "modern teacher-centred teach- } \\
\text { ing", mainly reproduction and } \\
\text { tendency to reorganization and } \\
\text { transfer of issues and circum- } \\
\text { stances }\end{array}$ & $\begin{array}{l}\text { using geomedia for explaining } \\
\text { environmental issues }\end{array}$ & 6 \\
\hline $\begin{array}{l}\text { Innovative educa- } \\
\text { tion for pupils } \\
\text { high level }\end{array}$ & $\begin{array}{l}\text { new learning arrangements, col- } \\
\text { laborative learning, constructivist } \\
\text { approach }\end{array}$ & $\begin{array}{l}\text { deconstructing spatial construc- } \\
\text { tions by using geomedia for } \\
\text { "learning by researching" in } \\
\text { groups }\end{array}$ & 10 \\
\hline $\begin{array}{l}\text { Fostering innova- } \\
\text { tiveness for pupils }\end{array}$ & $\begin{array}{l}\text { to pursue critical-emancipatory } \\
\text { interest }\end{array}$ & $\begin{array}{l}\text { developing hypotheses from data } \\
\text { visualized in gapminder, support } \\
\text { students development processes } \\
\text { by mapping. }\end{array}$ & 0 \\
\hline $\begin{array}{l}\text { Adoption of } \\
\text { innovation on } \\
\text { teacher level }\end{array}$ & $\begin{array}{l}\text { Adoption of technology or learn- } \\
\text { ing arrangements }\end{array}$ & $\begin{array}{l}\text { Preconditions of technology use } \\
\text { by teachers }\end{array}$ & 18 \\
\hline $\begin{array}{l}\text { Innovativeness on } \\
\text { teacher level }\end{array}$ & $\begin{array}{l}\text { to pursue critical-emancipatory } \\
\text { interest }\end{array}$ & $\begin{array}{c}\text { critical competences in geomedia } \\
\text { use }\end{array}$ & 1 \\
\hline Other & $\begin{array}{l}\text { Curriculum development, } \\
\text { project reports }\end{array}$ & & 11 \\
\hline
\end{tabular}

The actual analysis process is divided into the following steps (KUCKARTZ 2009):

- $\quad$ categories are developed,

- the text material is coded (marking text passages relevant for categorization),

- an overview of cases is compiled,

- in-depth analysis of selected examples (the last step, the in-depth analysis is a work in progress and is not mentioned here).

The 50 articles mentioning the keywords innovation, inventive, and innovative were further used for content analysis, which was supported by MAXQDA.

From the 50 reviewed papers (see Table 1), four were categorized in the category 'innovative technologies on pupils level', taking into account that those contributions only use innovative technologies to transport classic knowledge, instead of offering innovative educational concepts or even fostering innovativeness using geomedia. The usage of innovative technologies in school is mostly argued with the increase of motivation by learners as FILIPOV \& KOTSEV $(2011,148)$ mention in their contribution (...) "the change of student motivation, educational methods and curriculum, by introducing new techniques, corresponding to modern requirements (p. 150) (and that) the basic feedback from the leading geography teacher was that all students had been much more interested in the courses, 
when compared to previous years, when the method of collecting and presenting data on the map was done using more tradition methods and manual cartographic techniques."

In the category 'innovative education for pupils low level' six paper contributions were categorized. Contributions in this category used geomedia for a more teacher-centered approach, explaining i.e. environmental issues with the help of geomedia. As de MIGUEL GONZALEZ $(2012,322)$ mentioned in the following example:

"In second year of secondary education, the map of population of Spain by municipalities, taken from the map viewer SIANE is a resource which serves, not only to represent and locate the main demographic concentrations, and the major gaps in population, but also to explain the processes of population distribution comparing different magnitudes."

In the category 'innovative education for pupils high level', which involves new learning arrangements, collaborative learning, and constructivist approaches only ten of the 50 contributions were classified. An example for this category is the paper contribution by FEULNER \& KREMER (2014: 345), which presents the implementation of geogames in secondary education arguing the possibilities the Geogame Neocartographer has " $(t)$ he game offers the possibility to discover a small segment of space in a playful way, and therefore fosters the ability of spatial thinking, e.g. orientation in real spaces, the constructiveness of space, subjective mapmaking or different spatial perceptions"

In the category 'fostering innovativeness' none of the reviewed contributions could be categorized, as, per definition, none of the contributions pursue a critical emancipatory interest with their presented educational concepts.

Most of the reviewed contributions (18) were categorized within the category 'adoption of innovation on teacher level', since those mostly dealt with the preconditions of technology use by teachers.

Only one contribution on innovativeness on the teacher level (GRYL 2012: 190) argues for the reflexive use of geomedia "It seems important to combine learning situations that offer changes of perspectives with direct stimulation and methodological training to enable such changes."

Eleven contributions were categorized in the category 'others', addressing mostly curriculum development and project reports.

\section{Discussion}

While many papers use the term innovation and related terms excessively, close to none of them look or even aim for innovativeness on part of the end user. In general, it may be argued that most contributions mainly use the terms innovation / innovative without any regard to learning, as a reference to new media being employed in rather (or completely) traditional learning processes. These contributions do not, however, touch on the idea of fostering innovativeness in students; they rather try to give the subject - mostly geography - a 'modern' image. A second - and much smaller group - of papers discusses conditions under which teachers might be (early) adopters of new technologies, and typologies of teachers that might transfer a critical approach towards everyday geomedia to the classroom (KERSKI 2003; CARLOS \& SCHUBERT 2013). While these contributions do actually look into 
innovativeness in some respect, their target group and sample for their studies are teachers, not students. Again, most of the studies apply a very narrow conception of the adoption of innovation, centred around technology, and they do not discuss the wider field of innovativeness.

This is not to say that there is no way to foster innovativeness in students through geomedia at all. Both the analytical capabilities as well as the growing possibilities to communicate with geomedia make fostering innovativeness eminently possible. In a roundup on modern cartography and secondary school use, TRAUN et al. (2013) transfer ideas from visual analytics for learning processes, and are able to show that these are compatible with constructivist ideas of learning. They draw on work by CRAMPTON (2001; 2009), who redefines cartography as a visualisation for hypothesis generation instead of a communication device for results. We therefore may identify using maps and graphs as tools for hypotheses generation, and as a possible toolset for the reflexive and creative act of transforming an existing situation into a problem. We do, however, need to know more about the combination of information in students' minds. First ideas in this respect were presented by LANG (2012) and JEKEL (2014), who had students develop hypotheses from data visualized in gapminder. Empirical evaluation of this hypotheses generation process is yet to be provided, but small qualitative samples suggest that geo-visualisation actually fosters the generation of hypotheses, if used in interactive, open, learning environments, while 'perfect' visualisations may suppress hypotheses generation through its moment of 'awe' described in critical cartography literature.

Similar assumptions may hold true for the communicative elements of geomedia, as shown in studies by VOGLER \& HENNIG (2014). Here, the dimension in which an invention is implemented through participation and communication is the dimension of the innovation process. It may be argued that new technical developments from the geo-design world (GoODCHILD 2010, STEINITZ 2012) may increasingly support the communicative and participatory aspects of the spatial citizenship model. On a technical level, storytelling with the help of ArcGIS Online or similar products are a valid option.

In both dimensions, empirical research into the everyday strategies of hypotheses-generation and geo-communication as a basis for learning processes are conspicuous by their absence. We therefore regard research into the basics of innovativeness linked to geomedia a necessary and fruitful endeavour. Specifically, we suggest the following fields of research:

- Identification and operationalization of dimensions of innovativeness of individuals in respect to both the technical, as well as the social and political sphere. Looking into both dimensions allows the concept of innovativeness to be used in both science and citizenship education.

- Research into the support geomedia may provide for innovation processes, and more specifically invention, i.e. in the creation, structuring, and solving of problems. PPGIS and visual analytics here may be starting points, but basics of modelling may also provide useful support for invention.

- Research into everyday processes of the (re-)invention of the world through geomedia, i.e. the interpretative acts on part of the lay user as a basis for learning processes.

- Development of learning environments that foster innovativeness on the basis of the results of the above three dimensions. 


\section{Conclusion}

In this contribution, we suggest to clearly move on from bringing technical innovation into secondary school education, and instead concentrate on the contributions geomedia may provide to foster innovativeness in students on various levels. We provide some evidence supporting that this is not systematically the case so far, as innovative technologies, or even innovative learning environments, may not automatically lead to innovativeness. We support the idea that GI / geomedia does not live up to its potential in secondary education if we do not look into the role it may play to foster innovativeness.

\section{Acknowledgement}

Thanks are due to Gerold Olbrich, Wichmann Publishers/VDE for providing us with the full history of papers of the Learning with GI @ GI-Forum contributions in a digital format for analysis, as well as two reviewers.

\section{References}

Amin, A. \& Thrift, N. (1994), Living in the Global. In: AMIN, A. \& Thrift, N. (Eds.), Globalization, Institutions, and Regional Development in Europe. Oxford University Press, Oxford, 1-22.

BartoscheK, T. \& CARlos, V. (2013), What Happens when Teacher Training in Digital Geomedia is over? Case Studies Analyzing Levels of Pedagogical Integration. In: Jekel, T., Car, A., Strobl, J. \& Griesebner, G. (Eds.), GI_Forum 2013. Wichmann, Berlin/Offenbach, 437-446.

CrAmpton, J. (2009), Cartography: maps 2.0. Progress in Human Geography, 33 (1), 91100.

CRAMPTON, J. (2001), Maps as social constructions: power, communication and visualization. Progress in Human Geography, 25 (2), 235-252.

De Miguel GonZales, R. (2012), Map Viewers in Spain. Tools for Learning Geography in Schools. In: JeKel T., CAR, A., Strobl, J. \& Griesebner, G. (Eds.), GI_Forum 2012. Geovisualisation, Society and Learning. Wichmann, Berlin/Offenbach, 318-325.

Feulner, B. \& Kremer, D. (2014), Using Geogames to foster Spatial Thinking. In: Vogler, R., Car, A., Strobl, J. \& Griesebner, G. (Eds.), GI_Forum 2014. Geovisualisation, Society and Learning. Wichmann, Berlin/Offenbach, 344-347.

FILIPOV, L. \& KotSEV, A. (2011), Review of GI-Usage in the Bulgarian School System. In: Jekel, T., Koller, A., Donert, K. \& Vogler, R. (Eds.), Learning with GI 2011. Wichmann, Berlin/Offenbach, 144-151.

Godin, B. (2014), Innovation and Creativity. A Slogan, Nothing but a Slogan. Project on the Intellectual History of Innovation. Working Paper No. 17. www.csiic.ca/PDF/CreativityEnglish.pdf (15.4.2015).

Goodchild, M. F. (2010), Towards geodesign: Repurposing cartography and GIS? Cartographic Perspectives, 66, 7-21 
König, M. D., Battiston, M. D., Napoletano, M. D.\& Schweitzer, M. D. (2011), Recombinant knowledge and the evolution of innovation networks. Journal of Economic Behavior and Organization, 79 (3),145-164.

FROMHOLD-EISEBITH, M. (1995), Das kreative Milieu als Motor regionalwirtschaftlicher Entwicklung. Forschungstrends und Erfassungsmöglichkeiten. GZ, 83, 30-47.

GRYL, I. (2013), Alles neu - innovativ durch Geographie- und GW-Unterricht? GWUnterricht, 131, 16-27.

GRYL, I. \& JEKEL, T. (2012), Re-centering GI in secondary education. Towards a spatial citizenship approach. Cartographica 47, 1, 18-28.

Gryl, I., SANChez, E., Jekel, T., Juneau-Sion, C., Lyon, J. \& HöHnLE, S. (2014), Educational Uses of Geomedia. In: JEKEL et al. (Eds.), Learning and Teaching with Geomedia. Cambridge Scholars Publishing, Cambridge, 29-41.

JEKEL, T. (2014), Using a visual analytics approach for hypothesis generation. In: JEKEL et al. (Eds.), Learning and Teaching with Geomedia. Cambridge Scholars Publishing, Newcastle upon Tyne, 176-186.

JEKEL, T. (2007), "What you all want is GIS2.0". Collaborative GI based learning environments: spatial planning and education. In: CAR, A. et al. (Eds.), GI-Crossroads @ GIForum. Wichmann, Heidelberg, 84-89.

JEKEL, T. \& FROMHOLD-EISEBITH, M. (2003), Identität und Regionalwirtschaftliche Innovativität. Diskussion eines hypothetischen Zusammenhangs. Geographische Zeitschrift, 91 (2), 115-129.

LANG, R. (2012), Using Gapminder. GW-Unterricht, 126, 76-87.

KERSKI, J. J. (2003). The implementation and effectiveness of geographic information systems technology and methods in secondary education. Journal of Geography, 102, 128137.

KUCKARTZ, U. (2009), Einführung in die computergestützte Analyse qualitativer Daten. VS Verlag für Sozialwissenschaften, Wiesbaden.

RUTTEN, R. (Ed.) (2007), The learning region: foundations, state of the art, future. Elgar, Cheltenham.

SCHUlZE, U. \& KANWISCHER, D. (2012), Empirical GIS Education Research - A Review of Contributions to the GI-Forum. In: Jekel T., CAR, A., Strobl, J. \& Griesebner, G. (Eds.), GI_Forum 2012. Geovisualisation, Society and Learning, Wichmann, Berlin/Offenbach, 261-271.

STEINITZ, C. (2012), A framework for Geodesign. Changing Geography by design. ESRI Press, Redlands, CA.

TöDTling, F. (1994), The Uneven Landscape of Innovation Poles: Local Embeddedness and Global Networks. In: AmIN, A. \& THRIFT, N. (Eds.), Globalization, Institutions, and Regional Development in Europe. Oxford Iniversity Press, Oxford, 68-90.

Traun, C., Jekel, T., Loidl, M., Vogler, V., Ferber, N. \& GrYl, I. (2013), Neue Forschungsansätze der Kartographie und ihr Potential für den Unterricht. GW-Unterricht, 129, 5-17.

VOGLER, R. \& HENNIG, S. (2014), Using geomedia for collaborative learning environments - The example of participatory spatial planning. In: JEKEL, T., SANCHEZ, E., GRYL, I., JOUNEAU-SION, C. \& LYON, J. (Eds.), Learning and Teaching with Geomedia. Cambridge Scholars Publishing, Newcastle, 187-199. 